\title{
The everyday Budapest in 1914 - The Big War's heartland's in pictures.
}

\begin{abstract}
Conference held by Budapest City Archives, the Hungarian Academy of Science Research Centre of the Humanities, the National University of Public Service Faculty of Military Science and Officier Training, the Ministry of Defense Institute and Museum of Military History, and the LEGENDA Cultural Association.
\end{abstract}

Budapest, Hungary, 20 October 2014

The focus of the conference was on the heartland's everyday life, emphasizing the capital's place. Among the lecturers, we found the Budapest City Archives Deputy Head of Department Dr. András J. Horváth, who's presentation was titled "Budapest's life pictures in the light of private documents". Later on Dr. Iván Bertényi Jr., from ELTE's Department of Cultural History, presented his lecture, titled: "About the characteristics of the Hungarian propaganda during the $1^{\text {st }}$ World War". Next was Anikó Katona, the National Széchenyi Libary's art historian, who's presentation was tilted Posters on Pest's streets. The first section last presenter was assistant Professor Norbert Csibi, from the University of Pécs "Catholic public and religious life in Budapest, during the $1^{\text {st }}$ World War. The second section first presenter was Norbert Hlbocsányi, BFL's archivist, who introduced the war's economy, after him the ELTE's PhD student, Ferenc Maczó who's lecture was titled "In war country, Crowning Capital". The section's last presentation was presented by The National Archives of Hungary's archivist, János Balogh, titled "Lowetinszky's war". The third section's first subject was the Big War's Budapest in the presentation of ELTE PhD Gergely Bödök. Next was Olivér Perczel archivist's lecture "Entertainment and entertaining in Budapest in 1914". The conference closing presentation was made by the Hungarian Academy of Science Research Centre of the Humanities Institute of History's colleague, Csaba Katona, titled "The connection of Budapest's beer factories and the Army".

I asked in connection with Dr. Iván Bertényi Jr.'s lecture. My first question was about the main means of the propaganda. With regards to this, the historian emphasized the importance of posters, printed media, different kinds of postcards and stamps, and that these were under constant censorship. The encouragement of buying charity items and to make sacrifices, were also part of the propaganda. So to say it was expected obligation to provide support for the war, by buying those items, as well it was desired that the rich offered their jewelries and clothing. Those who didn't want to be stigmatized, in any form had to take part in making sacrifices. It was a kind of patriotism.

My next question was directed on the targeted group: for whom were these propagandas made for? Iván Bertényi stressed that the main priority was the persuasion of the educated people, because they were those who read news and were well informed. To my question about, whether in the capital or in the country sides were the successful, Bertényi answered that the faith in the country's victory and enthusiasm was more apparent within the cities. 
The farmers wanted to work, they were against the war, and because of the military loans thousands of families went bankrupt. From here on I asked the famous historian about in regards to the military defeats and hardships, how did the propaganda change? According to Iván Bertényi the whole of the military propaganda was defined by the idea of defending, that we were attacked and that it was a patriotic war. However, due to the immense hardships, taxpaying tendencies were steadily declining, and after the accession to the throne of Károly IV (1916-1918) the desire for peace was increasing within the means of the propaganda.

Zoltán MOLNÁR

Kodolányi János University of Applied Sciences Székesfehérvár, Hungary 